\title{
Low Back Pain in Female Caregivers in Nursing Homes
}

\author{
Hiroharu Kamioka ${ }^{1}$ and Takuya Honda ${ }^{2}$ \\ ${ }^{1}$ Department of Physical and Health Education, \\ Faculty of Environmental Science, \\ Tokyo University of Agriculture, \\ ${ }^{2}$ Department of Physical and Health Education, \\ Graduate School of Education, \\ The University of Tokyo, \\ Japan
}

\section{Introduction}

In recent years, Japan has become a fast-aging population with the greatest longevity in the world. According to the statistics of Japan, the proportion of the elderly aged 65 years or older reached $20.8 \%$ in fiscal, and is estimated to reach $39.6 \%$ in 2050 (Japanese Health, Labor, and Welfare Ministry, 2006).

In such an aged society, various health issues occur in caregivers in nursing homes. Particularly in female caregivers, high blood pressure (Hosono et al., 2009) and coronary heart disease (Lee et al., 2003) have been reported to be at high risk. Additionally, caregivers have high prevalence rates of low back pain (LBP) and a high incidence of worker's compensation claims for back injuries (Dehlin et al., 1976; Jorgensen et al., 1994; Fujimura et al., 1995). LBP is common in various occupations, its presence being related to activities requiring repetitive lifting and repeated activities for which anomalous postures tend to be adopted (Josephson et al., 1998). Such work characteristics are common among nursing caregivers. The prevalence of LBP in nursing is high in comparison with other occupations and in relation to other types of work (Ahlberg-Hulten et al., 1995). Risk factors include physical work such as manual lifting and transferring of patients, working conditions such as working time and rest during the night shift, and the working environment (Fujimura et al., 1995). Among these factors, exposures to frequent manual lifting and transferring of patients were widely recognized factors.

On the other hand, for female caregivers, it was reported that dissatisfaction with working conditions and the workplace environment was high (Fujimura et al., 1995), mental stress from work and human relations tended to be high (Ahlberg-Hulten et al., 1995; Failde et al., 2000), and physical fitness elements such as flexibility and muscular strength were low (Kinugasa et al., 1995). Caregivers in nursing homes perform shift work, including night work. In shift workers, a high risk of sleep interruption was reported (Nicholson et al., 1999). A study reported that caregivers who provided care at night suffered from a general 
sense of fatigue, physical disorders, and reduced mental energy compared with employed women (Tsukasaki et al., 2006). A systematic review indicated that female caregivers had higher levels of burden and depression, and lower levels of subjective well-being and physical health (Pinquart et al., 2006). Therefore, it is necessary that the issue of health in caregivers in nursing homes should include not only low back pain, but also mental and physical health status, and how to interpret these factors.

There are some exercise interventions for the lumbago patient (Cherkin et al., 1996; Frost et al., 1998; Kuukkanen et al., 1998), but so far there are few randomized controlled trials (RCTs) for caregivers in nursing homes. Furthermore, there is no study that assumed mental and physical health status as secondary outcome measurements. In a recent study (Bowen et al., 2009), there was an effort to attach great importance to the feasibility-like accumulation of evidence. Because the possibility of generalization is a serious matter, we needed to examine an intervention program with a few burdens to caregivers in a realistic care scenario. The objective of this review was to summarize the evidence from RCTs on the prevention and curative effects for LBP, and to suggest the concrete strategy as a future agenda.

\section{Methods}

\subsection{Criteria for considering studies included in this review}

\subsubsection{Types of studies}

Studies were eligible if they were RCTs.

\subsubsection{Types of intervention, language, and participant}

Studies included at least one treatment group in which all therapy was applied. The use of medication, exercise, alternative therapies or lifestyle changes are described, and must have been comparable in the groups studied. There was no restriction on the basis of language. In Japan, nursing is definitely distinguished from care but there are many countries in which this is not the case. Therefore nurses and nursing students were included as search terms. Furthermore, this study established the principal objective in relation to female caregivers, but target articles were included even if they had a small number of male caregivers relative to a majority of female caregivers.

\subsection{Search methods for studies identification (Bibliographic database)}

We searched the following databases from January 1, 1990 up to July 20, 2011: MEDLINE via PubMed, Web of Science. All searches were performed by a specific searcher (hospital librarian) who was qualified in medical information handling, and who was experienced in searches of clinical trials.

\subsection{Review methods}

\subsubsection{Selection of trials}

In order to make the final selection of studies for the review, all criteria were applied independently by two authors to the full text of articles that had passed the first eligibility screening. Disagreements and uncertainties were resolved by discussion. 


\subsubsection{Summary of studies and data extraction}

Two review authors selected the summary from each of the structured abstracts.

\subsubsection{Benefit, harm, and withdrawals}

The GRADE Working Group (Atkins et al., 2004) reported that the balance between benefit and harm, quality of evidence, applicability, and the certainty of the baseline risk were all considered in judgments about the strength of recommendations. Adverse events, withdrawals, and cost for intervention were especially important information for researchers and users of clinical practice guidelines, and we present this information with the description of each article.

\section{Results}

The literature searches included 352 potentially relevant articles (Figure 1). Abstracts from those articles were assessed and 11 papers were retrieved for further evaluation (checked for relevant literature). Five publications were excluded because they did not meet the eligibility criteria (see Appendix).

Manuscripts based on databases

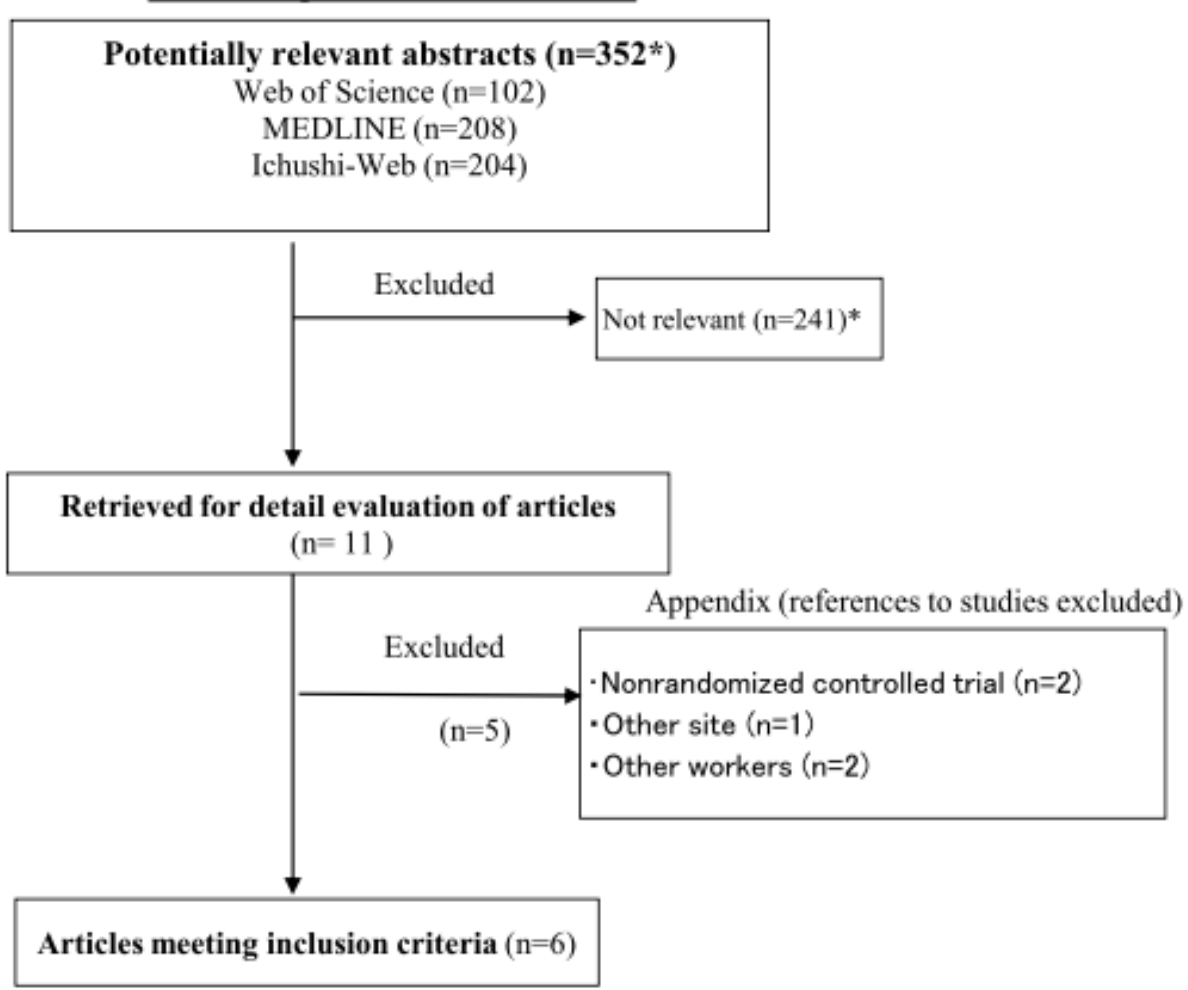

Fig. 1. Flowchart of trial process * reduplication 
Six studies met all inclusion criteria, and Table 1 presents the structured abstracts of these six articles. Table 2 provides a brief summary of the six articles. The types of intervention were as follows: multidimensional method (Miyamoto et al., 1998 and Svensson et al., 2008); transfer technique and stress management (Jensen et al., 2006); lumbar support (Roelofs et al., 2007); stretching exercise (Kamioka et al., 2011); and cognitive behavioral theory (Menzel et al., 2006).

\begin{tabular}{|c|c|c|}
\hline Author & Miyamoto M, et al. & Jensen LD, et al. \\
\hline Citation & $\begin{array}{l}\text { Orthop Surg Traumatol 1998; 41: 223-230. (in } \\
\text { Japanese with English abstract) }\end{array}$ & Spine 2006; $31: 1761-1769$. \\
\hline Setting/Place & Nippon Medical School Hospital & University Hospital of Aarhus \\
\hline Participants & $\begin{array}{l}\text { One hundred and forty-five female nurses (mean } 21.7 \\
\text { yrs, range; } 20-33 y r s \text { ) who were newly employed by the } \\
\text { hospital. }\end{array}$ & $\begin{array}{l}\text { A total of } 234 \text { home care workers, nurses, and nurse's } \\
\text { aides from } 3 \text { separate eldercare wards were invited to } \\
\text { participate in the trial. The invited eldercare workers } \\
\text { included all permanent staff engaged in client care at } \\
\text { the } 3 \text { wards. Of these } 234 \text { workers, } 210 \text { (90\%) agreed to } \\
\text { participate. The participation rate in the } 3 \text { wards was } \\
85 \% \text { (mean } 44.0 \pm 8.5 \text { yrs), } 96 \% \text { (mean } 44.6 \pm 9.8 \text { yrs), } \\
\text { and } 89 \% \text { (mean } 44.6 \pm 8.4 \text { yrs), respectively. }\end{array}$ \\
\hline Intervention & $\begin{array}{l}\text { The back school consisted of three courses; } \\
\text { a)introductory (lecture on biomechanics and physiology } \\
\text { of spine), b) intermediate (lecture on a) + body- } \\
\text { mechanics and the trunk muscle exercise for LBP } \\
\text { prevention), c) full-course (lecture of a)+b) and } \\
\text { exercise of LBP prevention. }\end{array}$ & $\begin{array}{l}\text { The TTI was based on the Stockholm training concept, } \\
\text { which aims to reduce the biomechanical load on the } \\
\text { back, minimize work in asymmetric postures, and } \\
\text { prevent sudden unexpected loads (Figure 2). The SMI } \\
\text { was developed to adress the work stress in health care } \\
\text { with particular attention to prevention of burnout and } \\
\text { development of stategies for stress management } \\
\text { (Figure 3). The reference groups had lessons of their } \\
\text { own choice in matters unrelated to the intervention } \\
\text { programs but of the same duration as the active } \\
\text { intervention lessons (e.g... on skin care, proper } \\
\text { treatment of a person with diabetes, work, and asthma } \\
\text { and safety procedures in chemicals handling). }\end{array}$ \\
\hline Main results & $\begin{array}{l}\text { The adherence of LBP exercise was good in order of } \\
\text { c,b,a, but the prevalence of LBP did not have a } \\
\text { significant difference among groups. However, in } \\
\text { subgroup analysis, high-intensity group }(>150 \text { days } / y) \\
\text { was lower than low-intensity group ( } 149 \text { days } / y) \text { in } \\
\text { prevalence of LBP. }\end{array}$ & $\begin{array}{l}\text { We found no difference in LBP in any of the } \\
\text { intervention arms over the study period. }\end{array}$ \\
\hline Conclusion & $\begin{array}{l}\text { The adherence of LBP exercise may produce good } \\
\text { effects on the prevention of LBP. }\end{array}$ & $\begin{array}{l}\text { The study showed no effect of a transfer technique or } \\
\text { stress management program targeting LBP. Thus, there } \\
\text { is a need for discussing other priorities in the } \\
\text { prevention of LBP among health care workers. }\end{array}$ \\
\hline
\end{tabular}

Table 1-a. Summary of articles based on structured abstracts 


\begin{tabular}{|c|c|c|}
\hline Author & Roelofs PDDM, et al. & Svensson AL, et al. \\
\hline Citation & Ann Intern Med. 2007; 147; 685-692. & Occupational Medicine 2009; 59: 563-569. \\
\hline Title & $\begin{array}{l}\text { Lumbar Supports to Prevent Recurrent Low Back Pain } \\
\text { among Home Care Workers }\end{array}$ & $\begin{array}{l}\text { Multidimensional intervention and sickness absence in } \\
\text { assistant nursing students }\end{array}$ \\
\hline Aim/Objective & $\begin{array}{l}\text { To determine the effectiveness of lumbar supports in } \\
\text { the secondary prevention of low back pain. }\end{array}$ & $\begin{array}{l}\text { To ascertain if a multidimensional prevention } \\
\text { programme combining psysical training. patient transfer } \\
\text { technique and stress management prevents sickness } \\
\text { absence and LBP in NA students. }\end{array}$ \\
\hline Setting/Place & Home care organization in the Netherlands & Two schools of health and social care in Copenhagen \\
\hline Participants & $\begin{array}{l}360 \text { home care workers with self-reported history of } \\
\text { low back pain. The lumbar support group }(n=183) \text { was } \\
\text { mean } 41.8 \pm 9.7 \text { yrs, and control group }(n=177) \text { was } \\
41.5 \pm 9.8 \text { yrs. }\end{array}$ & $\begin{array}{l}\text { The study population comprised } 766 \text { female NA } \\
\text { students from two schools of health and social care in } \\
\text { Copenhagen,Denmark. In all, } 668 \text { NA students from } 38 \\
\text { classes participated in the study. Students were } \\
\text { randomly allocated to the control or intervention } \\
\text { group, resulting in } 389 \text { students being assigned to the } \\
\text { intervention group ( } 20 \text { clusters; mean } 26 \pm 5 y r s \text { ) and } \\
279 \text { students to the control group ( } 18 \text { clusters; mean } \\
25 \pm 5 \text { yrs.). }\end{array}$ \\
\hline Intervention & $\begin{array}{l}\text { Short course on healthy working methods, with or } \\
\text { without patient-directed use of } 1 \text { of } 4 \text { types of lumbar } \\
\text { support. Participants could select } 1 \text { of } 4 \text { types of } \\
\text { lumbar supports, supplied by Bauerfeind B.V., Haarlem, } \\
\text { the Netherlands. LumboTrain and LumboTrain Lady are } \\
\text { individually adjustable, hook-and-loop fastening, fully } \\
\text { elastic supports that are available in } 5 \text { sizes for men } \\
\text { or women. }\end{array}$ & $\begin{array}{l}\text { The LBP prevention programme consisted of an } \\
\text { integrated approach of three preventive measures; } \\
\text { physical training }(48 \mathrm{~h}) \text {, patient transfer technique } \\
\text { education }(20 \mathrm{~h}) \text { and stress management with personal } \\
\text { development }(22 \mathrm{~h}) \text {. }\end{array}$ \\
\hline $\begin{array}{l}\text { Main and } \\
\text { secondary } \\
\text { outcomes* }\end{array}$ & $\begin{array}{l}\text { Primary outcomes were the number of days of low } \\
\text { back pain and sick leave over } 12 \text { months. Secondary } \\
\text { outcomes were the average severity of low back pain } \\
\text { and function (Quebec Back Pain Disability scale) in the } \\
\text { previous week. }\end{array}$ & $\begin{array}{l}\text { Sickness absence was self-reported. The question was } \\
\text { phrased 'how many days during the last } 12 \text { months } \\
\text { have you been absent due to your own sickness?' [17]. } \\
\text { Questions concerning LBP were taken from the } \\
\text { Standardisd Nordic Musculoskeletal Questionnaire } \\
{[18,19] \text {. }}\end{array}$ \\
\hline Main results & $\begin{array}{l}\text { Over } 12 \text { months, participants in the lumbar support } \\
\text { group reported an average of }-52.7 \text { days }(\mathrm{Cl},-59.6 \text { to }- \\
45.1 \text { days) fewer days with low back pain than } \\
\text { participants who received only the short course. } \\
\text { However, the total sick days in the lumbar support } \\
\text { group did not decrease ( }-5 \text { days [Cl, }-21.1 \text { to } 6.8 \\
\text { days]). Small but statistically significant differences in } \\
\text { pain intensity and function favored lumbar support. }\end{array}$ & $\begin{array}{l}\text { Of } 766 \text { female NA students, } 668 \text { ( } 87 \% \text { ) completed the } \\
\text { baseline questionnaire. Sickness absence during the } \\
\text { study period increased in both groups but the increase } \\
\text { was significantly lower in the intervention group than } \\
\text { the control group, mean (standard deviation) number of } \\
\text { days } 12(20) \text { versus } 18(34), P<0.05 \text {. The intervention } \\
\text { group reported no change in the mean level of general } \\
\text { health perception, energy/fatigue or psychological } \\
\text { well-being at follow-up, while the control group } \\
\text { reported a decline on those scales. There were no } \\
\text { significant differences in the prevalence of LBP at } \\
\text { follow-up between the intervention and control group. }\end{array}$ \\
\hline Conclusion & $\begin{array}{l}\text { Adding patient-directed use of lumbar supports to a } \\
\text { short course on healthy working methods may reduce } \\
\text { the number of days when low back pain occurs, but not } \\
\text { overall work absenteeism, among home care workers } \\
\text { with previous low back pain. Further study of lumbar } \\
\text { support is warranted. }\end{array}$ & $\begin{array}{l}\text { Compared to the control group, the intervention group } \\
\text { had significantly less sickness absence. The } \\
\text { intervention had no preventive effect on LBP } \\
\text { prevalence. }\end{array}$ \\
\hline
\end{tabular}

Table 1-b. Summary of articles based on structured abstracts 


\begin{tabular}{|c|c|c|}
\hline Author & Kamioka $\mathrm{H}$, et al. & Menzel NN, et al. \\
\hline Citation & Environ Health Prev Med (2011): 16: 97-105. & Pain Management Nurs 2006: 7: 53-63. \\
\hline Title & $\begin{array}{l}\text { Effectiveness of intervention for low back pain in } \\
\text { female caregivers in nursing homes: a pilot trial based } \\
\text { on multicenter randomization }\end{array}$ & $\begin{array}{l}\text { Back pain in direct patient care providers: early } \\
\text { intervention with cognitive behavioral therapy }\end{array}$ \\
\hline Aim/Objective & $\begin{array}{l}\text { To evaluate the intervention effect of a lecture and } \\
\text { stretching exercise on caregivers in nursing homes. }\end{array}$ & $\begin{array}{l}\text { To assess the feasibility and effect size of a cognitive } \\
\text { behavioral therapy (CBT) intervention to reduce the } \\
\text { measures of back pain, stress, and disability in direct } \\
\text { care providers working with back pain. }\end{array}$ \\
\hline Setting/Place & $\begin{array}{l}\text { The intervention program and the evaluation were } \\
\text { carried out in each nursing home, the locations of } \\
\text { which were as follows: nursing home A (Setagaya-ku, } \\
\text { Tokyo), nursing home B (Koshigaya City, Saitama } \\
\text { Prefecture), nursing home C (Konosu City, Saitama } \\
\text { prefecture), and nursing home D (Tomi City, Nagano } \\
\text { prefecture). }\end{array}$ & $\begin{array}{l}\text { The University of Florida Health Sciences Center } \\
\text { Institution }\end{array}$ \\
\hline Participants & $\begin{array}{l}\text { Of the } 88 \text { female caregivers (mean } 36.2 \pm 13.0 \text { yrs) in } \\
\text { the target population, all ( } 100 \% \text { ) consented to } \\
\text { participate when provided with enough explanation. } 44 \\
\text { were randomly assigned by lottery to the intervention } \\
\text { group and } 44 \text { to the control group. }\end{array}$ & $\begin{array}{l}\text { The participants included } 27 \text { female and } 5 \text { male nurses } \\
\text { or nursing assistants at } 550 \text {-bedtertiary care } \\
\text { academic medical center in Florida. The mean age of } \\
\text { participants was } 40.3 \text { years. }\end{array}$ \\
\hline Intervention & $\begin{array}{l}\text { The intervention program consisted of a lecture and } \\
\text { stretching exercise (Table } \\
\text { 1). The lecture, which lasted for } 30 \text { min, was given by } \\
\text { an orthopedist with extensive clinical experience ( } 20 \\
\text { years). The stretching exercise program consisted of } \\
\text { classical exercises aimed at the reduction and } \\
\text { prevention of lumbago. The program contained the } \\
\text { original eight elements of stretching based on the } \\
\text { William and Mackenzie exercises utilized widely in the } \\
\text { kinesitherapy of rehabilitation (Table 1). }\end{array}$ & $\begin{array}{l}\text { The cognitive behavioral therapy intervention was a } \\
\text { weekly stress and pain management session over } 6 \\
\text { weeks led by a clinical psychologist. The sessions } \\
\text { were held at the medical center and offered one day } \\
\text { per week either mid-afternoon (before the evening } \\
\text { shift began) or late afternoon (before day shift ended). } \\
\text { The topics covered were in relaxation techniques, } \\
\text { activity rest cycle, distraction techniques, cognitive } \\
\text { restructuring mini-relaxation on the job, on-the-job } \\
\text { stress management, assertiveness training, and sleep } \\
\text { hygiene/nutrition/exercise. }\end{array}$ \\
\hline
\end{tabular}

Main and A $10-\mathrm{cm}$ visual analogue scale (VAS) for low back pain Visual analogue scale (VAS) for low back pain was the secondary was the main outcome measurement. It was evaluated main outcome measurement. It evaluated whether the outcomes* whether the fingers of both hands could reach the fingers of both hands could reach the floor (fingerfloor (finger-floor distance: FFD) from a standing floor distance: FFD) from a standing position during position during anteflexion. anteflexion.

\begin{tabular}{|c|c|c|}
\hline Main results & $\begin{array}{l}\text { A total of } 29 \text { ( } 33 \% \text { ) participants withdrew by } 12 \text { weeks. } \\
\text { Regarding the reasons for withdrawal, } 28 \text { participants } \\
\text { resigned, and one took a leave of absence due to } \\
\text { exacerbation of lumbago. Adherence to the stretching } \\
\text { exercises was } 2.3 \pm 1.3 \text { (mean } \pm S D \text { ) times per } \\
\text { week. No significant differences were seen for any } \\
\text { outcome measurements. The high adherence group } \\
\text { ( } \geqq 3 \text { times per week) did not show a change in the } \\
\text { VAS, but the low adherence group ( }\langle 3 \text { times per week) } \\
\text { and control group showed a tendency towards an } \\
\text { increased score }(p=0.068 \text { ). }\end{array}$ & $\begin{array}{l}\text { Pain intensity scores declined in the intervention } \\
\text { group, indicationg a large effect }(p=0.06) \text {. However, } \\
\text { stress scores increased. Depression scores accounted } \\
\text { for one-third of the variance on hours absent because } \\
\text { of back pain. }\end{array}$ \\
\hline Conclusion & $\begin{array}{l}\text { Even with the conduct of one OJT, and exercises of } \\
\text { only } 6 \text { min every day, the adherence of caregivers was } \\
\text { low, and there appeared to be few effects of the OTJ. }\end{array}$ & $\begin{array}{l}\text { Although there was a hlgh dropout rate in the } \\
\text { intervention group, a cognitive-behavioral intervention } \\
\text { shows promise as a secondary prevention intervention. }\end{array}$ \\
\hline
\end{tabular}

*Two included studies did not distinguish main or secondary outcomes.

Table 1-c. Summary of articles based on structured abstracts 


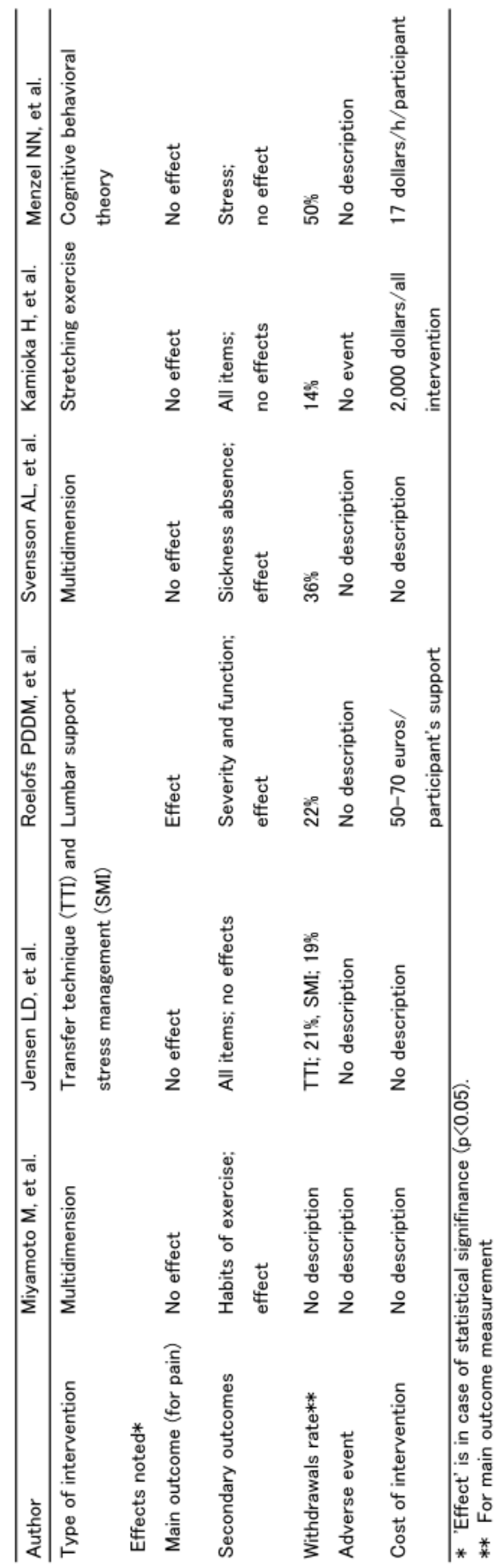

Table 2. Brief summary of six articles 
In the main outcome measurement (for pain-relieving), it was only lumbar support that was statistically significantly effective (Svensson et al., 2008). For the multidimensional interventions, it was only sick absence (Svensson et al., 2008) and exercise habits (Miyamoto et al., 1998) were statistically significantly effective in the secondary outcomes. Withdrawal rates were described in 5 articles, and tended to be high (14-50\%). Adverse events were not described in most articles.

Three articles did not provide information on the costs of intervention. For lumbar support, it cost 50-70 euros per one unit (Roelofs et al., 2007). For stretching exercise, it cost 2,000 dollars as an overall training expense (Kamioka et al., 2011). And, for cognitive behavioral intervention, the compensation to a participant of one hour was shown to be 17 dollars (Menzel et al., 2006).

We could not perform a meta-analysis due to the heterogeneity of the RCTs.

\section{Discussion}

\subsection{Overall evidence}

We did not use the CONSORT 2010 (Moher et al., 2010), example of an extension for trials assessing nonpharmacologic treatments (Boutron et al., 2008), and CLEAR-NPT checklists

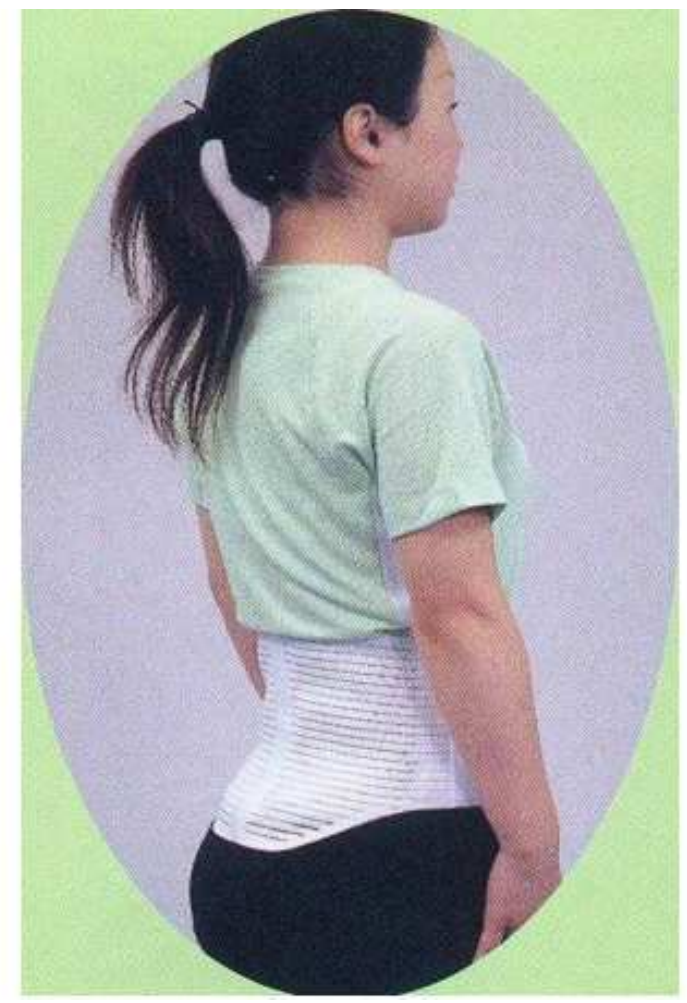

Fig. 2. A sample of lumber support for caregivers (made in Hakujuji corporation, Japan) 
(BoutronI et al., 2005) as quality assessments of articles. However, all studies had acceptably clear descriptions. Our study was able to clarify that coping with LBP was extremely difficult for female caregivers (nurses).

For LBP, it was a surprising fact that only lumbar support showed significant effect (Roelofs et al., 2007). The authors suggested that the experienced benefit (overall good adherence of wearing; 78\%) most likely outweighs the discomfort of the device (Figure 2). This device stabilizes the low back directly by letting the trunk work more. However, there is a concern that the muscular strength of the abdominal and back muscles will decrease when subjects continually use the device. Unfortunately, it is not known if this problem could be avoided by regulating the timing and duration of use of this device.

\subsection{Why other interventions were ineffective}

Five RCTs did not show the effects of interventions. A well designed RCT (Jensen et al., 2006) tried to evaluate the effectiveness of the Trans Technique Intervention (TTI; Table 3) and the Stress Management Intervention (SMI; Table 4) in reducing LBP, but both program had no effect on LBP status after 2 years. The authors suggested that the important question remain as to whether the lack of improvement in low back health in the active intervention arms is caused by insufficient implementation of the interventions or if it is the intervention itself that failed to produce better low back health. The authors also described a need for discussing other priorities in the prevention of LBP. Female caregivers always have a tight schedule in the workplace, which may be the main reason they are often not able to use the techniques that they learned. Therefore, we assume that even if an intervention program produces a lasting effect, continuous reinforcement is necessary.

In another well designed RCT (Svensson et al., 2008), a multidimensional program combining physical training, patient transfer technique and stress management had no preventive effect on LBP prevalence (sickness absence). The authors explained that it was sometimes hard to motivate patients to participate in the multidimensional program. We assume that the lack of motivation and readiness of the participants for the program produced a negative result. The authors emphasize that future studies for LBP should focus on the implementation of intervention programs in order to obtain precise information on participation and adherence.

In a RCT based on cognitive behavioral therapy (Menzel et al., 2006), a statistically significant effect was not observed. There was a high dropout rate $(50 \%)$ in the intervention group. The authors described that the participants either found attending a session at a specific time and day of week difficult or they judged the intervention to be not helpful. We assume this result was caused by a lack of motivation of the participant.

In our RCT (Kamioka et al., 2011), we evaluated the intervention effect of on-the-job training (OJT; a lecture by an orthopedist and stretching exercise) on caregivers in Japanese nursing homes. Unfortunately, even with conducting one OJT and exercising only six minutes every day, adherence of caregivers was low and there appeared to be few effects of the intervention. In the subgroup analysis for the high adherence group ( $>3$ times per week), lumbago tended to be reduced, but in the low adherence group ( 3 times per week $>$ ) and the control group, it tended to be worse $(p=0.068)$. This overall ineffectiveness could be attributed to poor adherence by the participants, which was also a problem in other trials. 
The TTI was based on the Stockholm training concept. The main principles in the concept are:

1. To reduce the biomechanical load on the back

2. To reduce asymmetric postures

3. To reduce the risk of sudden unexpected load

The technique can be used in all person transfers no matter whether the need is slight support or a transfer of totally dependent person. Lifting and sliding devices, adjustable bed, turntables and slings must be available. Transfer of disabled persons is performed according to the following guidelines

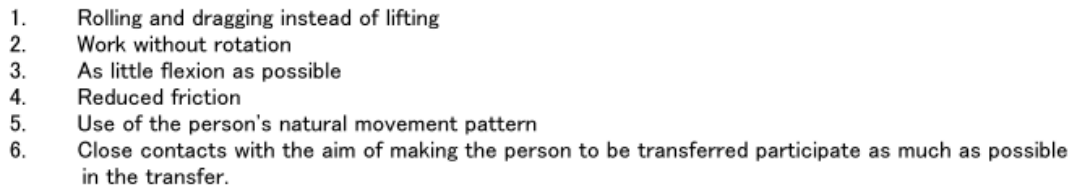

Four supervisors from the project were introduced and trained in the concept during a 3-day work shopby members of the Stockholm training group. The original Swedish manual was translated into Danish and provided the main contents of the education.

After the randomisation, all members of the 7 TTI groups received $2 \times 4$ hours of introduction in the basic principles of the training concept, mainly classroom education where each person was trained in about 30 transfer situations. One or two persons from each of the 7 TTI groups volunteered to become instructors, 11 altogether. The instructors were trained for 30 hours in a combination of practical and theoretical lessons in accordance with the concept at the start of the Intervention period. The following 2-6 months focused on implementation of the concept where the instructors had the floor responsibility for supervising their colleagues by observation and bedside education. Besides this ongoing task, the instructors took part in educating the newly employed and formed the link to the occupational health service in matters concerning ergonomics. The instructors established a network and met every second month during the study period to maintain and develop their competence.

Table 3. Contents of the Transfer Technique Intervention (TTI) (Jansen et al., 2006)

The purpose of the SMI programme was to reduce work stress by enhancing coping with stress, preventing burn out and strengthening communication skills. An experienced occupational psychologist developed the program and instructed two fellow psychologists to ensure that the process and the education became similar in the $6 \mathrm{SMI}$ groups. The training took place over 20 weeks with group sessions every fortnight, each session lasting 2 hours. Between sessions, the participants were given assignments concerning implementation of the themes of the session in their daily practice. In addition, every person had her own developing project based on her personal answers from the baseline questionnaire.

Contents of the SMI programme:

1. Analysis of the organisation with the aim of establishing a collective understanding of the resources and weaknesses of the group. This analysis was used to define the developing project for the group with the goal of reducing the psychosocial strain at work.

2. Work with feed back, introduction of criticism and praise as a model of development. Group task concerning self-care.

3. Prevention of burn out, use of tools to recognise connection of one's own demands and others' expectations.

4. Introduction of a model for collegial supervision, establishing ethical rules and selection of subject for collegial supervision.

5. Practical collegial supervision training, examples of stress in different work situations. Introduction of a method to appraise stress.

6. Further work with stress reduction and conflict solving.

7. Behavior related stress and coping strategies, working with personal strategies for coping with stress.

8. Roles and group dynamics. Negotiation of new roles. Internal dialogue about stress.

9. Practicing stress management

10. Status of the personal and collective developing projects and planning of future activities.

A representative from each group volunteered to become a instructor with responsibility for maintaining the process and solving upcoming problems. Like in the TTI, the instructors formed a network with meetings every second month.

Table 4. Contents of the Stress Management Intervention (SMI) (Jansen et al., 2006) 


\subsection{Future educational program and research agenda}

\subsubsection{Educational program agenda}

Figure 3 shows the educational program for prevention of LBP in nursing facility. First, based on transtheoretical model, identification of the stage of the participant is necessary. Second, before the main interventions, researchers should perform a thorough orientation to promote understanding of the program. Included in the contents of the program should be loss and profit for oneself by participating and protecting one's body, and success and failure samples that are easy to understand. However, unfortunately, in spite of such efforts, it is assumed that there are a few caregivers who will be indifferent or refuse to participate. It is important to the orientation to transfer caregivers to more progressive behavior stages. Greater effects from performing main interventions can be expected when a participant is ready and has enough understanding of the program. In addition, the intervention program should be performed repeatedly and continuously. However, in this concept model, cost-benefit is not considered.

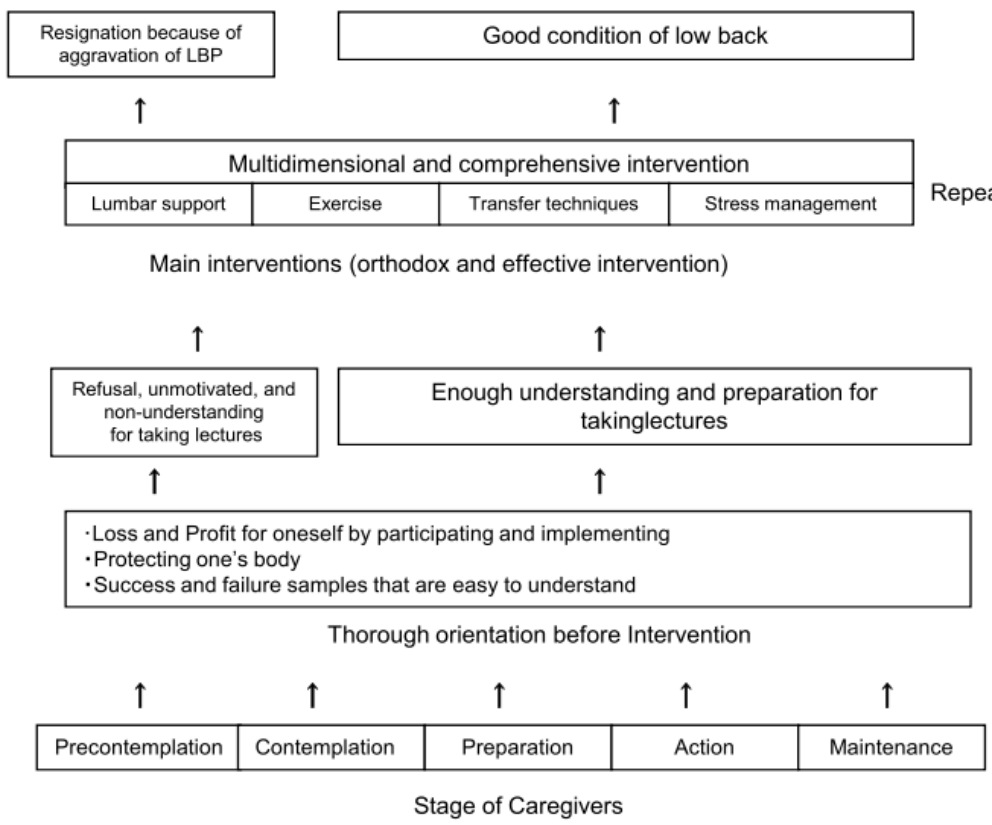

Fig. 3. Concrete educational program for prevention of LBP in nursing facility (Kamioka \& Honda, 2011)

\subsubsection{Research agenda}

Table 5 shows the current evidence (strength of effect) and future research agenda for various interventions. Researchers should present not only the efficacy data, but also any adverse events or harmful phenomena. In particular, they should clarify problems such as muscle weakness caused by wearing lumbar support too often. In various intervention methods, the re-inspection of an effect by an appropriate study design is necessary. It is essential to scientifically explain the mechanism of effect at the same time. Furthermore, in the exercise intervention, it is 
necessary to make the details of at exercise kind (contents), frequency, time and the period clear. Researcher must judge whether caregiver can enforce them as adherence practically.

\begin{tabular}{|c|c|c|}
\hline Type of intervention & Evidence of effects & Research agenda \\
\hline Lumbar support & Strong & $\begin{array}{l}\text { Study about the timing of the use } \\
\text { Study on adverse event such as muscle weakness }\end{array}$ \\
\hline Transfer technique & Weak or poor & Can the person whom a skill is high in prevent LBP? \\
\hline Stress management & Weak or poor & For stress-relieving the degree of effect? \\
\hline & & The mechanism of effect of LBP prevention by stress-relieving? \\
\hline Exercise & Weak or poor & $\begin{array}{l}\text { The combination of exercise that effect is high in? } \\
\text { The degree of effect of a person having high adherence? }\end{array}$ \\
\hline Cognitive behavioral theory & Weak or poor & $\begin{array}{l}\text { For cognitive befavior the degree of effect? } \\
\text { The mechanism of effect of LBP prevention by cognitive befavior? }\end{array}$ \\
\hline Multidimension & Weak or poor & The most suitable combination of intervention methods? \\
\hline
\end{tabular}

Table 5. Current evidence and future research agenda

\subsection{Study limitations}

This study was based on the PRISMA statement (Liberati A et al., 2009) except for the metaanalysis. However, there were several limitations to the study. Some selection criteria were common across studies, as described above, but bias remained due to differences in eligibility for participation in each study. Publication bias was also a limitation. Although there was no linguistic restriction in the eligibility criteria, we searched studies with only English and Japanese key words. Furthermore, we could not check the references by a hand search. In addition, a nursing job (in a hospital) is essentially different from a care job (in a nursing facility), but, depending on the country, these are approximately similar working institutions. Therefore, an information bias by having included both may exist.

\section{Conclusions}

For LBP, it was a surprising fact that only lumbar support showed a significant effect. Female caregivers are always on a tight schedule in the workplace, which may be the main reason they are often not able to use the techniques that they learned. Therefore, we assume that even if an intervention program produces a lasting effect, continuous reinforcement is necessary. Initially, based on a transtheoretical model, identification of the stage of the participant is necessary. Then, prior to the main interventions, researchers should perform a thorough orientation to promote understanding of the program. Contents of the program should include loss and profit for oneself by participating and protecting one's body, and success and failure samples that are easy to understand.

In various intervention methods, re-inspection of the effect from an appropriate study design is necessary. It is essential to scientifically explain the mechanism of the effect at the same time.

\section{Acknowledgments}

We would like to express our appreciation to Ms. Makishi M. and Ms. Higashino R. for their cooperation in this study. 


\section{Appendix}

References to studies excluded in this review

\begin{tabular}{|c|c|c|c|}
\hline $\begin{array}{l}\text { Excusi- } \\
\text { on no. }\end{array}$ & $\begin{array}{l}\text { Author. Journal } \\
\text { (Year) }\end{array}$ & Title & $\begin{array}{l}\text { Reason of } \\
\text { exclusion }\end{array}$ \\
\hline 1 & $\begin{array}{l}\text { Rossignol M, et al. } \\
\text { Spine (2000) }\end{array}$ & $\begin{array}{l}\text { Coordination of primary health care for } \\
\text { back pain }\end{array}$ & $\begin{array}{l}\text { Not nurse or } \\
\text { caregivers }\end{array}$ \\
\hline 2 & $\begin{array}{l}\text { Dahl JC, et al. } \\
\text { Eur J Pain (2001) }\end{array}$ & $\begin{array}{l}\text { Evaluation of a randomized preventive } \\
\text { behavioural medicine work site } \\
\text { intervention for public health workers at } \\
\text { risk for developing chronic pain }\end{array}$ & $\begin{array}{l}\text { Pain of neck, } \\
\text { shoulder, and } \\
\text { back }\end{array}$ \\
\hline 3 & $\begin{array}{l}\text { Maul I, et al. } \\
\text { Eur Spine J (2005) }\end{array}$ & $\begin{array}{l}\text { Long-term effects of supervised physical } \\
\text { training in secondary prevention of low } \\
\text { back pain }\end{array}$ & $\begin{array}{l}\text { All employees } \\
\text { of a large } \\
\text { hospital }\end{array}$ \\
\hline 4 & $\begin{array}{l}\text { Pedersen MT, et al. } \\
\text { Spine (2007) }\end{array}$ & $\begin{array}{l}\text { Back muscle response to sudden trunk } \\
\text { loading can be modified by training } \\
\text { among healthcare workers }\end{array}$ & $\begin{array}{l}\text { Nonrandomiz } \\
\text { ed controlled } \\
\text { trial }\end{array}$ \\
\hline 5 & $\begin{array}{l}\text { Porru S, et al. } \\
\text { Med Lav (2009) }\end{array}$ & $\begin{array}{l}\text { Prevenzione dei disturbi del rachide nei } \\
\text { lavoratori di un ospedale: intervento } \\
\text { multidisciplinare e valutazione di efficacia }\end{array}$ & $\begin{array}{l}\text { Nonrandomiz } \\
\text { ed controlled } \\
\text { trial }\end{array}$ \\
\hline
\end{tabular}

\section{References}

Ahlberg-Hulten, G.K.; Theorell, T. and Sigala, F. (1995). Social support, job strain and musculoskeltal pain among female health care personnel. Scand J Work Environ Health, Vol. 21, pp.435-439

Atkins, D.; Best, D.; Briss, P.A.; Eccles, M. et al. (2004). Grading quality of evidence and strength of recommendations. BMJ, Vol. 328, pp.1490-1497

Boutron, I.; Moher, D.; Tugwell, P. et al. (2005). A checklist to evaluate a report of a nonpharmacological trial (CLEAR NPT) was developed using consensus. J Clin Epidemiol, Vol. 58, pp.1233-1240

Boutron, I.; Moher, D.; Altman, D. et al. (2008). Methods and processes of the CONSORT group: example of an extension for trials assessing nonpharmacologic treatments. Ann Inter Med, Vol.148, pp.W60-66

Bowen, D.J.; Kreuter, M.; Spring, B. et al. (2009). How we design feasibility studies. Am J Prev Med, Vol. 36, pp. 452-457

Cherkin, D.C.; Deyo, R.A.; Street J.H. et al.(1996). Pitfalls of patient education: limited success of a program for back pain in primary care. Spine, Vol.21, pp. 345-355

Dehlin, O.; Hedenrud, B. and Horal, J. (1976). Back symptoms in nursing aides in a geriatric hospital. Scand J Rehab Med, Vol.8, pp. 47-53

Failde, I.; Gonzalez, J.L.; Novalbos, J.P. et al. (2000). Physical and occupational predictive factors for back pain among employees of a university hospital in southern Spain. Occup Med, Vol.50, pp.591-596

Frost, H.; Lamb, S.E.; Moffett, J.A.K.; et al. (1998). A fitness programme for patients with chronic low back pain: 2-year follow-up of a randomized controlled trial. Pain, Vol.75, pp.273-279 
Fujimura, T.; Yasuda, N. and Ohara, H. (1995). Work-related factors of low back pain among nursing aides in nursing homes for the elderly. J Occup Health, Vol.37, pp.89-98

Health \& Welfare Statistics Association of Japan. (2006). Annual Statistical Report of National Health Conditions. pp.8-24 (in Japanese)

Hoshino, J.; Hori, Y.; Kondo, T. et al. (2009). Physical and mental health characteristics of female caregivers. Jpn J Public Health, Vol.56, pp.75-86 (in Japanese with English abstract)

Jensen, L.D.; Gonge, H.; Jors, E. et al. (2006). Prevention of low back pain in female eldercare workers: randomized controlled work site trial. Spine, Vol.31, pp.1761-1769

Jorgensen, S.; Hein, H.O. and Gyntelberg, F. (1994). Heavy lifting at work and risk of genital prolapse and herniated lumbar disk in assistant nurses. Occup Med,Vol. 44, pp.47-49

Josephson, M. and Vingard, E. (1998). Workplace factors and care seeking for low-back pain among female nursing personnel: MUSIC-Norrtalje Study Group. Scand J Work Environ Health,Vol.24, pp.465-472

Kamioka, H.; Okuizumi, H.; Okada, S. et al. (2011). Effectiveness of intervention for low back pain in female caregivers in nursing homes: a pilot trial based on multicenter randomization. Environ Health Prev Med, Vol.16, pp.97-105

Kinugasa, T.; Nagasaki, H.; Ito, H. et al. (1995). Effect of physical fitness, sports activities, and aging on low back pain for women working in nursing home. Jpn J Phys Educ, Vol.40, pp. 151-160 ( in Japanese with English abstract)

Kuukkanen, T. and Malkia, E. (1998). Effects of a three-month active rehabilitation program on psychomotor performance of lower limbs in subjects with low back pain: a controlled study with a nine-month follow-up. Perceptual Motor Skills, Vol.87, pp. 739-753

Lee, S.; Colditz, G.A.; Berkman, L.F. and Kawachi, I. (2003). Caregiving and risk of coronary heart disease in U.S. women. Am J Prev Med, Vol.24, pp.113-119

Liberati, A.; Altman, D.G.; Tetzlaff, J. et al. (2009). The PRISMA statement for reporting systematic reviews and meta-analyses of studies that evaluate health care interventions: explanation and elaboration. Ann Intern Med, Vol.151, pp.W65-94

Menzel, N.N. and Robinson, M.E. (2006). Back pain in direct patient care providers: early intervention with cognitive behavioral therapy. Pain Manag Nurs, Vol.7, pp.53-63

Miyamoto, M.; Shirai, Y.; Takeuti, T. et al. (1998). Prospective study for the occurrence of low-back pain in newly-employed nurses educated at the back school. Orthop Surg Traumatol, Vol.41, pp.223-230 (in Japanese with English abstract)

Moher, D.; Hopewell, S.; Schulz, K.F.; et al. (2010). CONSORT 2010 explanation and elaboration: updated guidelines for reporting parallel group randomized trials. BMJ, Vol.340, c869

Nicholson, P.J. and D'Auria D.A.P. (1999). Shift work, health, the working time regulations and health assessments. Occup Med, Vol.49, pp. 127-137

Pinquart, M. and Sorensen, S. (2006). Gender differences in caregiver stressors, social resources, and health: an updated meta-analysis. J Gerontol Psych Sci, Vol.61B, pp. P33-45

Roelofs, P.D.; Bierma-Zeinstra, S.M.; van Poppel, M.N. et al. (2007). Lumbar supports to prevent recurrent low back pain among home care workers: a randomized trial. Ann Intern Med, Vol.147, pp.685-692

Stensson, A.L.; Stroyer, J.; Ebbehoj, N.E. et al. (2009). Multidimensional intervention and sickness absence in assistant nuring students. Occup Med, Vol.59, pp.563-569

Tsukasaki, K.; Kido, T.; Makimoto, K. et al. (2006). Naganuma R, Ohno M, Sunaga K. The impact of sleep interruptions on vital measurements and chronic fatigue of female caregivers providing home care in Japan. Nurs Health Sciences, Vol.8, pp.2-9 


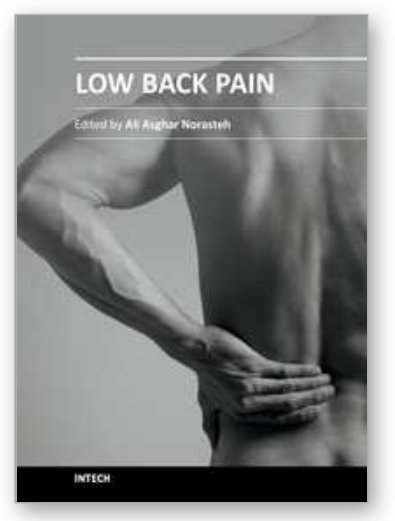

\section{Low Back Pain}

Edited by Dr. Ali Asghar Norasteh

ISBN 978-953-51-0599-2

Hard cover, 352 pages

Publisher InTech

Published online 09, May, 2012

Published in print edition May, 2012

This book includes two sections. Section one is about basic science, epidemiology, risk factors and evaluation, section two is about clinical science especially different approach in exercise therapy. I envisage that this book will provide helpful information and guidance for all those practitioners involved with managing people with back pain-physiotherapists, osteopaths, chiropractors and doctors of orthopedics, rheumatology, rehabilitation and manual medicine. Likewise for students of movement and those who are involved in re-educating movement-exercise physiologists, Pilates and yoga teachers etc.

\section{How to reference}

In order to correctly reference this scholarly work, feel free to copy and paste the following:

Hiroharu Kamioka and Takuya Honda (2012). Low Back Pain in Female Caregivers in Nursing Homes, Low Back Pain, Dr. Ali Asghar Norasteh (Ed.), ISBN: 978-953-51-0599-2, InTech, Available from:

http://www.intechopen.com/books/low-back-pain/low-back-pain-in-female-caregivers-in-nursing-homes

\section{INTECH}

open science | open minds

\author{
InTech Europe \\ University Campus STeP Ri \\ Slavka Krautzeka 83/A \\ 51000 Rijeka, Croatia \\ Phone: +385 (51) 770447 \\ Fax: +385 (51) 686166 \\ www.intechopen.com
}

\author{
InTech China \\ Unit 405, Office Block, Hotel Equatorial Shanghai \\ No.65, Yan An Road (West), Shanghai, 200040, China \\ 中国上海市延安西路65号上海国际贵都大饭店办公楼 405 单元 \\ Phone: +86-21-62489820 \\ Fax: $+86-21-62489821$
}


(C) 2012 The Author(s). Licensee IntechOpen. This is an open access article distributed under the terms of the Creative Commons Attribution 3.0 License, which permits unrestricted use, distribution, and reproduction in any medium, provided the original work is properly cited. 